\title{
Монгол хүний бичиг үсгийн чадварын судалгаа (албан ёсны кирилл үсгийн жишээн дээр) (= Исследование письменной грамотности среди монголов (на примере официального кириллического письма))
}

\section{Гэрэлма Гуруучин ${ }^{1}$, Дарья Бадмаевна Гедеева ${ }^{2}$}

\author{
${ }^{1}$ Институт языка и литературы АН Монголии (г. Улан-Батор, Монголия) \\ докт. фил. наук (Ph. D), старший научный сотрудник, доцент \\ E-mail: g_mgl2003@yahoo.com
}
${ }^{2}$ Калмыцкий научный центр РАН (д. 8 , ул. И. К. Илишкина, 358000 Элиста, Российская Федерация) кандидат филологических наук, ведущий научный сотрудник (iD) 0000-0002-8735-9184. E-mail: gedeevadb@kigiran.com

\author{
(c) КалмНЦ РАН, 2020 \\ (С) Гэрэлма Г., Гедеева Д. Б., 2020
}

Аннотация. Введение. В 1970 г. в Монголии на официальном уровне началось обучение кириллице, что способствовало успешной борьбе с неграмотностью в стране. Все принимавшие участие в этом проекте специалисты были награждены золотой медалью Н. К. Крупской от ЮНЕСКО. Исследование современного состояния письменной грамотности связано с социолингвистической проблематикой обучения монгольскому языку и письменности. Кроме того, монголы используют для общения в Интернете латиницу, а с 2025 г., согласно принятым законам, в официальном документообороте, наряду с кириллицей, будет использоваться монгольская национальная письменность. В связи с этим возникла необходимость изучения письменной грамотности среди монголов в использовании кириллицы. Цель. В данной работе мы исследуем современное состояние письменной грамотности среди монголов, определяем перспективы и изучаем опыт других стран в подобных проектах. В этих целях в рамках социально-лингвистического исследования с использованием статистических методов был выполнен анализ материала, изучены социальные факторы и законодательная база, влияющие на письменную грамотность. Bblводы. В опросе принимали участие представители более 10 разных профессий - учителя, парикмахеры, повара, математики, государственные служащие, студенты и пенсионеры, разделенные на три возрастные категории. Результаты исследования показывают, что уровень письменной грамотности, а также способности составить самостоятельно текст составляет 47,5 \% в возрастной категории 16-30 лет, 78,4 \% — в категории 31-40 лет и 52,1 \% — для лиц старше 41 года. В совокупности уровень кириллической грамотности в указанных возрастных категориях составляет $59,3 \%$. Определенное беспокойство вызывает влияние использования латиницы на кириллическую грамотность среди представителей молодежи 16-30 лет. 
Ключевые слова: кириллица, способность, возрастная классификация, тест, социолингвистическое исследование

Благодарность. Материалы статьи апробированы на Международной научной онлайнконференции «Монголоведение в начале XXI в.: современное состояние и перспективы развития - II», проведенной при финансовой поддержке РФФИ (проект № 20-09-22004) и частичной поддержке гранта Правительства РФ (№ 075-15-2019-1879).

Для цитирования: Гэрэлма Г., Гедеева Д. Б. Монгол хүний бичиг үсгийн чадварын судалгаа (албан ёсны кирилл үсгийн жишээн дээр) (= Исследование письменной грамотности среди монголов (на примере официального кириллического письма)) // Монголоведение. 2020. Т. 12. № 4. С. 625-634. (На монг.). DOI: 10.22162/2500-15232020-4-625-634

UDC 811.512 .31

DOI: $10.22162 / 2500-1523-2020-4-625-634$

\title{
Exploring Written Literacy of Mongolians: The Official Cyrillic Writing System
}

\section{Gerelma Guruchin ${ }^{1}$, Daria B. Gedeeva ${ }^{2}$}

\author{
${ }^{1}$ Institute of Language and Literature, Mongolian Academy of Sciences (54A, Enkhtaivan \\ (Peace) Ave., Bayanzurkh District, Ulaanbaatar 13330, Mongolia) \\ Ph.D., Senior Research Associate, Associate Professor \\ E-mail: g_mgl2003@yahoo.com
}
${ }^{2}$ Kalmyk Scientific Center of the RAS (8, Ilishkin St., Elista 358000, Russian Federation) Cand. Sc. (Philology), Leading Research Associate
iD 0000-0002-8735-9184. E-mail: gedeevadb@kigiran.com

\author{
(C) KalmSC RAS, 2020 \\ (C) Gerelmaa G., Gedeeva D. B., 2020
}

\begin{abstract}
Introduction. The aricle studies the Cyrillic literacy of Mongolians through the use of sociolinguistic methods. Mongolians had been using the Mongolian script from ancient times through 1921, and since then by the 1930s the traditional script was replaced because it was considered obsolete and feudal. In 1941, Mongolia officially switched to modified Latin alphabet which was used for some time. However, two months later this decision was cancelled, and three months thereafter Cyrillic alphabet was introduced - on March 25, 1941, the Mongolian People's Republic officially adopted the Cyrillic writing system. Mongolian script has been taught at secondary schools since the mid-1980s and under the influence of democracy and transparency, the national idea of the public has revived, and their current desire is to use the national script officially. Mongolians also use the Latin script in the Internet and mobile telephony. The Law on Mongolian Language was approved in 2013 and is being implemented, and this law stipulates that from 2025 onwards official documents shall be written in Cyrillic and Classical Mongolian. Results. The work investigates how Mongolians use three writing systems - Cyrillic, Latin and Traditional Mongolian. However, the official script (and literacy to be assessed) is still Cyrillic. The paper uses methods of social linguistics to assess Cyrillic literacy among citizens aged 16-30, 31-40, and over 40.
\end{abstract}


The Cyrillic literacy skills are as follows: $16-30$ year olds $-47.5 \%, 31-40$ year olds $78.4 \%, 41$ and older $-52.1 \%$. The average value of Cyrillic literacy skills across all the three age groups is $59.3 \%$. The influence of Latin alphabet on Cyrillic skills for 16-30 year olds proves a matter of concern.

Keywords: Cyrillic literacy, skills, age classification, test, sociolinguistic method

Acknowledgements. The article was presented at the International scientific online conference 'Mongolian Studies at the Beginning of the $21^{\text {st }}$ Century: Current State and Development Prospects - II' funded by RFBR (project no. 20-09-22004) and Government of Russia (grant no. 075-15-2019-1879).

For citation: Gerelmaa G., Gedeeva D. B. Exploring Written Literacy of Mongolians: The Official Cyrillic Writing System. Mongolian Studies (Elista). 2020. Vol. 12. No. 4. Pp. 625-634. (In Mong.). DOI: 10.22162/2500-1523-2020-4-625-634

\section{Судалгааны хэсэг}

Бид судалгаандаа бусад улс гүрэн эх хэлэндээ хэрхэн хандаж буй туршлагаас суралцахын тулд Япон улсыг сонгон авч танилцаа. Япон улсын Боловсрол, соёл, шинжлэх ухаан, спортын яам нь япон хүний эх хэлний чадварт анхаарал хандуулж, жил бүрийн «Эх хэлний талаарх олоннийтийн судалгаа»-нд тулгуурлан Эх хэлний зөвлөлд асуудлыг хэлэлцүүлж цаашид хэрэгжүүлэх бодлогоо тодорхойлдог юм байна. Мөн нийгмийн хөгжил, технологийн дэвшилтэй холбоотой гаднаас орж ирж буй харь хэлний үгийг катакана үсгээр тэмдэглэн, утгыг тайлбарласан «Утгын тайлбар толь»-ийг тухайн онд шинэчлэн гаргадаг байна. Бидний санаа авч хэрэгжүүлмээр нэг зүйл нь ард олны дунд «Үгийн өдөр», «Жилийн ханз», «Хайкү шүлгийн уралдаан», «Номын санг нэмэгдүүлэх» зэрэг үйл ажиллагааг нутаг тус бүр зохион байгуулдаг нь үгийн утгыг таниулахын зэрэгцээ эх хэлний талаарх мэдлэг, сонирхолыг үргэлж бий болгож эх хэлээ сурталчлах үйл ажиллагааг олон нийтийн мэдээллийн хэрэгслээр дамжуулан өргөн сурталчилдаг байна.

\section{Монгол хүний бичиг үсгийн чадварыг судалсан нь}

Бид энэ удаа өдгөө албан ёсоор хэрэглэгдэж буй кирилл бичиг үсгийн өнөөгийн чадварын судалгааг хийлээ.

Монгол улс 1941 оны 3 сарын 25-нд болсон МАХН-ын Төв хороо, Сайд нарын зөвлөлийн хамтарсан хурлаас шинэ үсгийг зохиох ажлыг нэг сарын дотор МАХН-ын Төв хорооны тэргүүлэгчид ба Засгийн газарт оруулж батлуулахыг Ю. Цэдэнбал даргатай комисс (орлогч дарга Машлай, гишүүд Гонгоржав, Доржсүрэн, Лувсанвандан, Дамдинсүрэн, Сүрмаажав, Далхжав, Цэвэгмид, Тамжид, Лувсандорж)-т даалгаснаар кирилл үсгийг албан ёсоор хэрэглэх эхлэл тавигджээ [Шагдарсүрэн 2001: 189]. Улмаар «Орос үсэг дээр үндэслэсэн монгол шинэ үсэг батлах тухай» Ардын сайд нарын зөвлөл, МАХН-ын Төв хорооны Тэргүүлэгчдийн 1941 оны 5 сарын 9-ний өдрийн хамтарсан хурлаар, орос үсэгт үндэслэн 35 үсэгтэй кирилл үсгийг батлан, түүнийг бичих ба хэрэглэх урьдчилсан дүрмийг долоо хоногийн дотор боловсруулан гаргаж зарлах ба цагаан толгой, сурах бичгийг ойрын хугацаанд бэлтгэн гаргахыг ШУХ, Ардыг гэгээрүүлэх яаманд даалгаж «...бага сургуулийн 1, 2-р ангиудад 31-32 оны хичээлийн жилээс эхлэн бүх хичээлийг шинэ үсгээр явуулсугай» гэж тогтоожээ [Шагдарсүрэн 2001: 190]. Кирилл үсгийг түргэн сургахад саад гарсан нь дэлхийн хоёрдугаар дайн бөгөөд дайн дуусмагц 1945 оны 5 сарын 18-нд 
болсон БНМАУ-ын Сайд нарын зөвлөл, МАХН-ын Төв хорооны хамтарсан хурлаар «...бүх хэвлэл ба улсын албан хэргийг 1946 оны 1 сарын 1-нээс эхлэн шинэ үсгээр явуулсугай...» гэж тогтоож, Ц. Дамдинсүрэн 1942 онд хэвлэсэн шинэ үсгийн дүрмээ засварлан 1946 онд «Монгол шинэ үсгийн товч дүрэм» нэртэйгээр гаргасныг мөрдөж эхэлжээ. ЭнэхүҮ «Монгол шинэ үсгийн товч дүрэм»-ийн гол гол зүйлийг бусад монгол бичгийн нэгэн адил үсэг зүйн үүднээс орос цагаан толгойн гучин нэгэн үсэг, хоёр тэмдэгтийг хэвээр авч дээр нь $\Theta$, Y-г нэмээд нийт 35 үсэг, тэмдэгтэй болгожээ. Дүрэмд «...шинэ үсгийн a, о, у, э, ө, Ү, Ы, и, й, я, е, ё, ю энэ 13 нь эгшиг, б, в, г, д, ж, з, к, л, м, н, п, р, c, т, ф, х, ц, ч, ш, щ 20 нь гийгүүлэгч үсэг, ь, ъ хоёр нь дуудлагагүй тул эгшиг ч биш, гийгүүлэгч ч биш зүгээр тэмдэг үсэг болно...» хэмээн тайлбарлажээ. Кирилл үсгийг сургах хөдөлгөөнийг МАХН-ын Төв хорооны 1946 оны 4 сарын хурлаар 16-40 насны бүх хүмүүс ялангуяа нам эвлэлийн гишүүдийг шинэ үсэгт заавал сургах журам тогтоосны сацуу энэ ажлыг улсын төлөвлөгөөгөөр хийж, биелүүлсэн сумд, хүмүүсийг шалгаруулан шагнах болзол хүртэл гаргаж байв. Энэ үйл ажиллагаанд улсаас 1941-1948 оны хооронд 6314070 төгрөг зарцуулж [Чулуунбаатар 2002: 210] мөн давтан сургах зэргээр тасралтгүй үйл ажиллагаа явуулсны үрээр хөдөөгийн малчныг хүртэл сургаж чаджээ. Иргэн бүрээ бичиг үсэгт сургасны төлөө ЮНЕСКО-оос 1970 онд Хэл зохиолын хүрээлэнг Н. К. Крупскаягийн нэрэмжит бичиг үсэг үл мэдэх явдлын устгасны төлөө «Алтан медаль»-иар шагнаж байжээ.

Кирилл үсгийг албан ёсны бичиг үсэг болгон хэрэглэсээр 1990-ээд он гарахад нийгмийн байдал өөрчлөгдөн олон ургальч үзлийн үүднээс бичиг үсэгт хандах хандлага өөр болж үндэсний монгол бичиг болон латин үсгийг авах гэсэн санал цөөнгүй гарах болсон билээ. Энэ байдалд иргэд хэрхэн хандаж байгааг ШУА-иас 2007 онд судлан үзэхэд нийт оролцогсдын 8,4 \% монгол бичгийн, 4,4 \% нь латин үсгийг хэрэглэх, 72,6 \% нь кирилл үсгийг албан ёсны бичиг хэвээр байлгах саналтай [Ширнэн 2006: 159-163] дүн гарсан бол хоёр дахь удаагийн судалгаагаар нийт оролцогсдын 64,9 \% нь төрийн албан хэргийг кирилл монгол бичгээр хөтлөх ёстой гэж үзсэн бол 31 \% нь уйгаржин монгол бичгээр, 3.7 \% нь латин бичгээр хөтлөх нь зүйтэй хэмээн тус тус үзжээ [Хэлний бодлогыг оновчтой болгох асуудал 2007: 21]. Эдгээр судалгааг харьцуулан үзэхэд төрийн албан хэргийг кирилл үсгээр хөтлөн явуулъя гэсэн санал давамгай байгаа нь харагдаж байна.

Дээрх судалгаанаас үндэслээд одоо үед хүмүүсийн бичиг үсгийн чадвар хэрхэн ямар байгааг судлан үзэх нь бичиг үсгийн болоод хэлний бодлогод чухал байна. Иймээс бид монгол хүний бичиг үсгийн чадварыг тогтоохдоо нийгмийн дотор орж, өөрийн аргаа боловсруулан эх хэрэглэгдэхүүнээ цуглуулан нийгэм хэл шинжлэлийн дүгнэлт хийсэн [Бондалетов 1987: 8]. Судалгааны аргын хувьд насны ангиллыг голчлон үзэж 3 ангилав. Үүнд:

- 18-30 нас;

- 31-40 нас;

- 41-60 насны ангиллаар авч үзлээ.

Судалгаанд багш, тогооч, үсчин, оюутан, жолооч, эдийн засагч, бизнесийн удирдлага, орчуулагч зэрэг 10 гаруй мэргэжлийн 58 хүнийг хамруулж нийгэм хэл шинжлэлийн судалгаа хийлээ. 
Кирилл бичгийн чадварыг шалгахдаа нийт оролцогчдоос

- $\quad$ зөв бичгийн дүрмийн сорил;

- ажилд орох өргөдөл бичих сорил авлаа.

\section{Зөв бичих чадварын судалгаа}

Зөв бичих чадварын судалгааг үсгийн дүрмийн шаардлагатай монгол хэлний хэл зүйн хэлбэр залгасан 6 үг, гадаад хэлнээс орж ирсэн 4 үг нийтдээ 10 үгийг хэлж бичүүлэн оролцогч бүрээс тус тусад нь шалган үзэв.

Насны ангиллаар авч үзвэл, эхний бүлэг 18-30 насны 23 хүний кирилл бичгийн чадварын түвшин 47,5 \% -тай байлаа. Үүнээс бүрэн дунд боловсролтой нь 6, дээд боловсролтой нь 17 хүн байсан бөгөөд энэ бүлгийн дотор сорилоос ямар нэгэн оноо аваагүй бүгдийг хийгээгүй 1 хүн байв. Энэ бүлгийнхний хамгийн дээд чадвартай нь сорилын 60 орчим хувийг гүйцэтгэсэн нь харагдаж байна. Энэ насныхан зөв бичгээр бичихдээ латин үсэг хольж $t, d$ гэх зэргээр бичих, мөн гээгдэх эгшгийн дүрмийг мэдэхгүйгээс алдсан тохиолдол их байлаа. Иймээс энэ бүлгийн нийт чадварын судалгаа 50 хувиас доогуур гарсан байна. Бичиг үсгийн хэлбэр сайнгүй гаргацтай муутай бичсэн байх нь түгээмэл байв.

Хүснэгт А. Кирилл бичгийн чадварын судалгаа

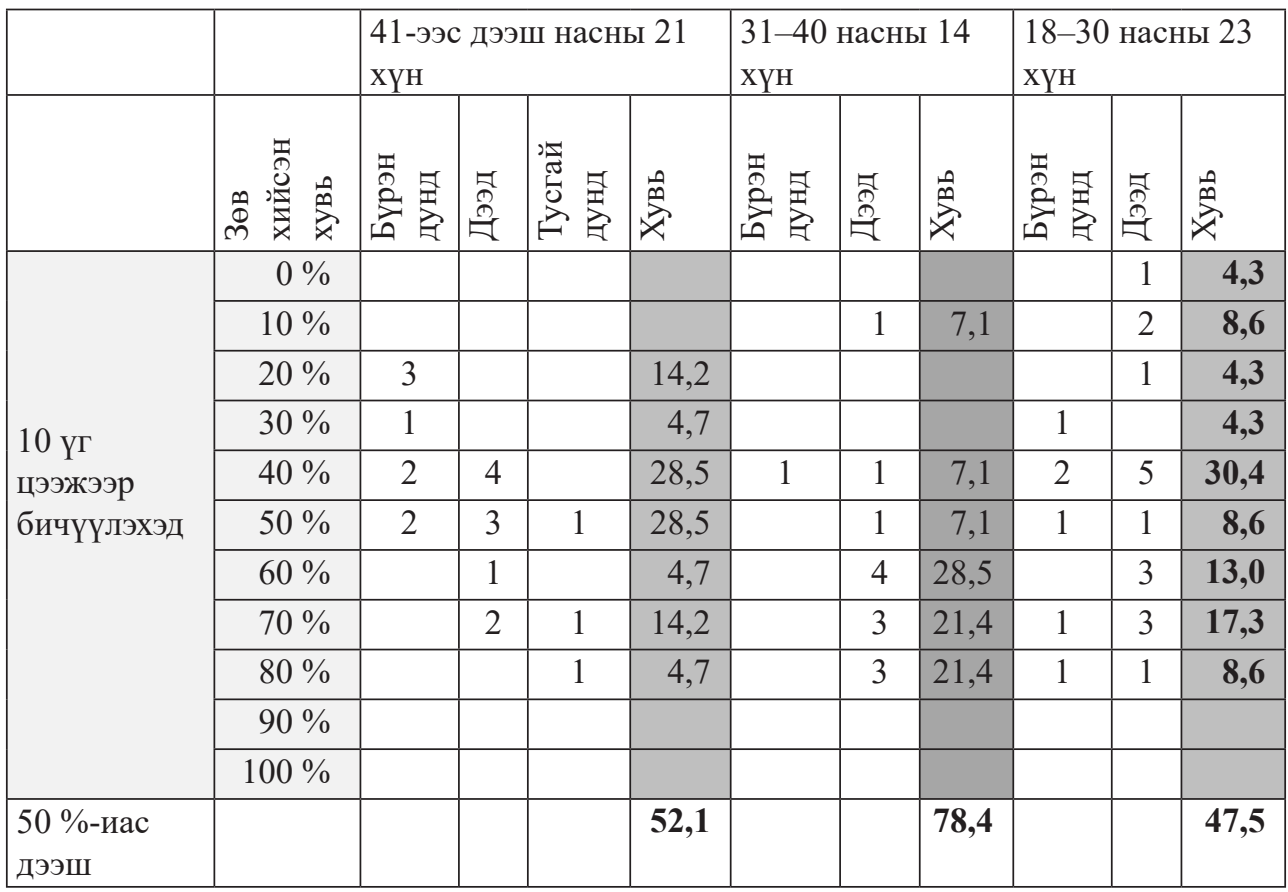

41-ээс дээш насны 21 хүний кирилл бичгийн чадварын түвшин 52,1 \% -тай байлаа. Энэ насны хүмүүс монгол үгийн зөв бичих дүрмийг сайн мэдэж байгаа боловч нийтлэг ажиглагдсан зүйл нь гадаад үгийг буруу бичих хандлагатай байна. Англи хэлнээс орж ирэн түгээмэл хэрэглэгдэж буй үгсийг ресейпшин, рсепшин, ресеепшн гэх зэргээр дуудлагаараа янз бүр бичиж байсан юм. Энэ бүлэгт дээд, тусгай дунд, бүрэн дунд сургууль төгссөн боловсролын түвшинтэй хүмүүсийг хамруулж үзэхэд алдааны хувь нь 14,2 \%-аас эхэлж буй нь өмнөх бүлгээс чадварын хувьд харьцангуй илүү байгаа нь харагдаж байна. 
31-40 насны 14 хүний кирилл бичгийн чадварын түвшин 78,4 \%-тай байлаа.

Кирилл бичгийн хамгийн өндөр чадвартай насны бүлэг бөгөөд тэд 10 үг тутмаас 8-ыг нь бичиж чадаж байна гэсэн үг. Нийтлэг алдаа нь гээгдэх эгшийн дүрмийг ихэнхдээ алдаж байв.

Найруулгын болон учир зүйн чадварын судалгаа (Ажилд орох өргөдөл)

Кирилл бичгийн зөв бичих чадвараас гадна 58 хүнээс өргөн хэрэглээний албан баримт болох ажилд орох өргөдөл бичүүлж, түүнийгээ найруулга болон учир зүйн үүднээс зөв эсэхийг нь шалгаж үзвэл дараах байдалтай байв. Үүнд:

- Найруулгын алдаатай 53,4 \% нь буюу 31 хүн;

- Учир зүйн алдаатай 15,5 \% нь буюу 9 хүн;

- Огт алдаагүй 46,5 \% нь 27 хүн байв.

Ажилд орох өргөдөл бичсэн байдлыг үзвэл, албан бичгийн найруулгын өнгө аясыг гажуудуулан хэлзүйн хэлбэрийг «ажилд орох хүсэлтэй байна, ажилд орохыг хүсч байна» гэх зэргээр бичсэн байхын сацуу өөрийн хаана, ямар сургууль төгсөж, мэргэжил эзэмшсэн талаар дутуу танилцуулсан байна.

Учир зүйн алдаа нь гол төлөв өөрийгөө товч танилцуулаагүйгээс үүдэн гарсан бөгөөд «танай байгууллагад ажилд орох хүсэлтэй байна» гэсэн үгээр хязгаарлагдаж байна. Үүнийг нэгэн ажилд орох өргөдлөөр жишээлбэл,

«Нас 18, эрэгтэй, бүрэн дунд боловсролтой хүний ажилд орох өргөдөл.

Өргөдөл гаргах нь

Миний бие Энхтөрийн БилгүҮн ажилд орох өргөдөл гаргах нь:

Би өмнө нь ажлын дадлага туршлага сургуулийн болон хуваараа 2 жил хийсэн турилагатай. Мөн мэргжлийн диплом, 12 төгссөн гэрчилгээтэй, мэргэжлийн онол болон практиктай. Спортын талд гэвэл хөлбөмбөг сайн тоглодог эвэсэлтэй болон мөн хурдан сурах чадвартай. Намайг ажсилд авбал 2 талдаа ашигтай гэдэгт бат илтгэлтэй байна» хэмээн бичснээс үзвэл ямар байгууллагад орох гэж буй, ямар мэргэжил эзэмшсэн зэрэг нь тодорхойгүй байхын сацуу өргөдлийн загварыг мэдэхгүй байгаа нь харагдаж байна.

\section{Бичиг усгийн чадварт нийгмийн орчин нөлөөлөх нь}

Бидний хийж буй судалгаа нь дан ганц кирилл үсгийн чадварын судалгаа биш бөгөөд бичиг үсгийн хэрэглээнд нөлөөлж буй нийгмийн харьцаа хамаарлыг өөр өөр нас сэтгэхүйн түвшинд [Гэрэлмаа 2012: 8] судлан үзэхийг зорьсон юм.

Нийгмийн байдалтай нь уялдуулан үзвэл, 18-30 насныхан 1990 он, түүнээс хойш төрсөн хүмүүс багтах бөгөөд тэдний нийгмийн орчинд латин үсэг болон монгол бичиг тодорхой хэмжээгээр нөлөөлж байгаа учраас латин үсгээр хольж бичдэг 3 хүн байхын сацуу монголоор огт бичдэггүй англиар бичдэг гэсэн 1 байв. Энэ нь тухайн бичигт үсгийн чадварт анхлан сурсан хэлний нөлөөл байдгийг харуулж байгаа юм.

31-40 насныханд анх бичиг үсэг сурахдаа үндэсний монгол бичгээр сурсан хүн 4 байв. Гэсэн хэдий ч энэ насныхан бичихдээ дан кирилл үсгээр бичдэг гэж хариулж байгаа нь тэдний ажил хөдөлмөр идэвхтэй эрхэлдэг настай холбоотой байна.

41-ээс дээш насныхан онцлог нь дан кириллээр бичдэг хэмээн хариулсан нь тэдэнд ЕБДС-д монгол бичиг заагаагүй, латин үсгийн хэрэглээ байгаагүйтэй холбоотой юм. 
Мөн 3 хүнээс бусад нь төрөлх монгол хэлнээсээ гадна 24 хэл мэддэг гэсэн байгаа нь насны ангиллаас үл хамаарсан нийтлэг байдал байв.

58 хүнээс 48 хүн нь кирилл үсгийг дангаар нь тогтмол хэрэглэдэг гэсэн байна. Харин латин үсгээр бичдэг 5 хүн түүнээс 1 хүн монгол бичгээр бичдэг, 4 нь кирилл болон латин үсгийг хольдог гэсэн санал өгчээ.

Анхлан сурсан бичиг үсэг нь гадаад хэлээр сурсан 3, монгол бичгээр сурсан 4, хариулаагүй 10, кирилл бичиг сурсан нь 41 байлаа.

Бичиг үсгийн чадварыг сайжруулж байдаг хамгийн гол хэрэглүүр нь ном унших байдаг. Өнөөгийн хүмүүс ном яаж уншиж байгааг цаг хугацаа болон унших хэлбэрээр асуулгын аргаар судлан үзвэл, хариулаагүй болон уншаагүй хүний тоо 35 байгаа нь дундажаас доогуур үзүүлэлт гарч байна.

ХУснэгт Б. Ном уншсан тухай судалгаа

\begin{tabular}{|c|c|c|c|c|c|c|c|c|}
\hline & & 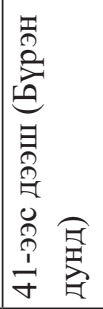 & 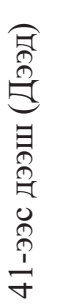 & 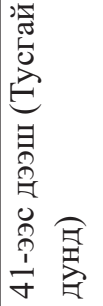 & 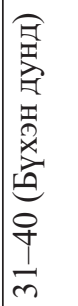 & 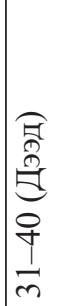 & 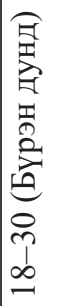 & $\begin{array}{l}\widehat{\hat{~}} \\
\hat{\Omega} \\
\stackrel{⿹}{\Xi} \\
0 \\
\tilde{D} \\
\infty \\
0\end{array}$ \\
\hline \multirow{6}{*}{$\begin{array}{l}\text { Хэдэн хэл } \\
\text { эзэмшсэн }\end{array}$} & 0 & & 1 & & & 2 & & \\
\hline & 1 & 5 & 2 & 1 & 1 & 2 & & 7 \\
\hline & 2 & 2 & 5 & 1 & & 5 & 3 & 8 \\
\hline & 3 & & 1 & 1 & & 2 & 2 & 1 \\
\hline & 4 & & 1 & & & & & 1 \\
\hline & Хариулаагүй & 1 & & & & 2 & 1 & \\
\hline \multirow{4}{*}{$\begin{array}{l}\text { Анхлан } \\
\text { сурсан үсэг, } \\
\text { бичиг }\end{array}$} & $\begin{array}{l}\text { Монгол (кирилл } \\
\text { үсэг) }\end{array}$ & 8 & 7 & 2 & 1 & 7 & 4 & 12 \\
\hline & Монгол бичиг & & & & & 4 & & \\
\hline & Гадаад хэл & & 1 & & & & 1 & 1 \\
\hline & Хариулаагүй & & 2 & 1 & & 2 & 1 & 4 \\
\hline \multirow{6}{*}{$\begin{array}{l}\text { Ашиглаж } \\
\text { буй бичгийн } \\
\text { хэлбэр }\end{array}$} & $\begin{array}{l}\text { Дан кириллээр } \\
\text { бичдэг }\end{array}$ & 7 & 6 & 2 & 1 & 11 & 4 & 15 \\
\hline & $\begin{array}{l}\text { Монгол бичгээр } \\
\text { бичдэг }\end{array}$ & & 1 & & & & & \\
\hline & Латин үсэг хольдог & & 1 & 1 & & & 1 & 2 \\
\hline & $\begin{array}{l}\text { Англи болон бусад } \\
\text { гадаад хэлээр бичдэг }\end{array}$ & & 1 & & & & 1 & \\
\hline & $\begin{array}{l}\text { Дан кирилл ба } \\
\text { монгол бичиг }\end{array}$ & & 1 & & & & & \\
\hline & Хариулаагүй & 1 & & & & 2 & & \\
\hline
\end{tabular}




\begin{tabular}{|c|c|c|c|c|c|c|c|c|}
\hline \multirow{8}{*}{$\begin{array}{l}\text { Сүүлийн } \\
\text { сард уншсан } \\
\text { номын тоо }\end{array}$} & Уншаагүй & & 1 & & 1 & 3 & 1 & 4 \\
\hline & 1 & 3 & & & & 2 & & 2 \\
\hline & 2 & 3 & & 1 & & 4 & 4 & 7 \\
\hline & 3 & & & 1 & & & & \\
\hline & 4 & & & & & 1 & & \\
\hline & 5 & & 2 & & & & & 1 \\
\hline & 5 -аaс дээш & & 2 & & & 1 & & \\
\hline & Хариулаагүй & 2 & 3 & 1 & & 2 & 1 & 3 \\
\hline \multirow{4}{*}{$\begin{array}{l}\text { Ном уншдаг } \\
\text { хэлбэр }\end{array}$} & Цаaсаap & 6 & 3 & 3 & & 5 & 4 & 11 \\
\hline & Цахимаар & & 2 & & & 1 & & 2 \\
\hline & Аль алинаар нь & & 3 & & & 4 & & 1 \\
\hline & Хариулаагүй & 2 & 2 & & 1 & 3 & 2 & 3 \\
\hline
\end{tabular}

\section{Бичиг усэгт нөлөөлэс буй эрх зүйн орчны байдлыг судалсан нь}

Нийгэм хэл шинжлэлийн судалгааны нэг тал нь хүний чадварт нөлөөлөх нийгмийн хүчин зүйлүүдийг судлах бөгөөд эдгээрийн нэг нь эрх зүйн орчин юм. Иймээс бид бичиг үсгийн чадварт нөлөөлж болох төрөөс баримтлах бодлогын баримт бичгүүд болон Боловсролын тухай хууль, Монгол хэлний тухай хуулиудад түүний нэмэлт өөрчлөлт зэргийг судалж дүн шинжилгээ хийв.

БНМАУ-ын Анхдугаар Үндсэн хуулийг 1924 онд батлахад ард олныг эрдэм соёлд гэгээрүүлэх, элдэв ухааны эрдэмд бүрнээ үнэ төлбөргүйгээр боловсруулах тухай заалт оруулж байснаас хойш эрх зүйн орчинд олон шинэчлэл, өөрчлөлт хийсээр иржээ. 1982 онд БНМАУ-ын Ардын их хурал «Ардын боловсролын тухай» хуулийг батлан гаргаснаар бүх шатны боловсролын харилцааг нэгтгэн зохицуулж байв. 1991 онд Улсын Бага Хурлаас «БНМАУ-ын боловсролын хууль»-ийг батлан гаргаж өмнөх 1963, 1982 оны боловсролын тухай хуулийн нэгэн адил бүх шатны боловсролын харилцааг нэгтгэн зохицуулсан шинжтэй байсан хэдий ч тухайн үеийн нийгмийн тогтолцооны шинэчлэл, боловсролын хөгжлийн чиг хандлагыг харгалзан үзсэн шинэлэг зохицуулалтуудыг агуулсан. Тухайлбал, хувийн хэвшлийн боловсролын байгууллага байгуулж болох, албан болон албан бус аль ч хэлбэрээр боловсрол эзэмших боломжтой болох талаарх асуудлыг тусгасан. Энэ хууль нь сургуулийн тухай бус боловсролын тухай хууль байснаараа ихээхэн онцлогтой байсан юм.

1991 онд Улсын Бага Хурлаас төрийн албан хэргийг сурагч, оюутнууд, нийт иргэдэд монгол бичгийг зааж сургах, багш бэлтгэх, ном, сурах бичиг зохион хэвлүүлэх, заах арга боловсруулах зэрэг далайцтай ажил өрнөсөн. Гэвч 1994 онд албан хэргийг монгол бичгээр хөтлөн явуулах бэлтгэл хангагдаагүй гэж үзээд албан хэрэг болон сургалтыг кирилл бичгээр явуулахаар шийдвэрлэсэн юм. Монгол Улсад боловсролын талаар баримтлах дараах төрийн бодлогын баримт бичгүҮдийг УИХ-аас баталжээ.

- Монгол Улсын төрөөс боловсролын талаар баримтлах бодлого, 1995 онд;

- Монгол бичгийн үндэсний хөтөлбөр, 1995 онд;

- Монгол Улсын Латин үсгийн үндэсний хөтөлбөр, 2003 онд тус тус баталжээ.

Үүнээс харахад манай улс кирилл үсгээ хэрэглэхийн сацуу үндэсний монгол бичиг, латин бичгийг зэрэгцүүлэн хөгжүүлэх зорилт тавьсан байна. 
УИХ-аас 1995 онд «Монгол бичгийн үндэсний хөтөлбөр»-ийг баталж, монгол бичиг сурах идэвхийг нэмэгдүүлэх, бүх шатны сургуульд монгол бичиг заах ажлыг үе шаттай хэрэгжүүлэхэд чиглэсэн зорилтуудыг тусгаж хэрэгжүҮлжээ.

Монгол улсад интернет үйлчилгээ, тоон технологи нэвтэрч, үүний дагуу монгол кирилл үсгийг латин үсгээр янз бүрийн хэлбэрээр орлуулан хэрэглэснээр зөв, буруу ойлголцох, монгол хэлний нэгдмэл байдал алдагдах болсон гэж үзээд «Латин үсгийн үндэсний хөтөлбөр»-ийг баталжээ.

Монгол Улсын Их Хурлаас баталсан дээрх бодлогын баримт бичгүҮдэд тулгуурлан Засгийн газраас боловсролын салбарт 1997-2005 онд хийх өөрчлөлтийн үндсэн чиглэл (1997), Монгол бичгийн үндэсний хөтөлбөр-1, Бүх нийтэд суурь боловсрол эзэмшүүлэх үндэсний хөтөлбөр (1995), Англи хэлний сургалтын чанарыг сайжруулах үндэсний хөтөлбөр (2001) зэрэг бодлогын баримт бичгүүд батлагдан хэрэгжсэн байна. Түүнчлэн Боловсролын багц хууль (1995, 1998, 2002, 2006, 2008), Сургуулийн өмнөх боловсролын тухай хууль (2008), Монгол Улсын Боловсролыг 2006-2015 он хүртэл хөгжүүлэх мастер төлөвлөгөө (2006), Бичиг үсгийн боловсролын үндэсний хөтөлбөр (2004) зэрэг хэрэгжсэн.

«Бичиг үсгийн боловсролын үндэсний хөтөлбөр (2004)»-т дараах зорилт тавигджээ. Үүнд: «бичиг үсгийн боловсролын таатай орчин бүрдүүлэх үндсэн дээр бичиг үсэг үл мэдэх явдлыг бүрмөсөн устган 2008 онд насанд хүрэгчдийн бичиг үсэгт тайлагдалтын түвшинг 99,0 хувиас доошгүй хэмжээнд хүргэх» гэж заасан нь кирилл үсгийн чадварыг хөгжүүлэх тухай заалт юм. Хүн ам, орон сууцны 2010 оны улсын тооллогоор хүн амын бичиг үсгийн мэдлэг 98,3 хувьтай байна гэсэн дүн гарчээ.

Боловсролын асуудлыг зохицуулж байгаа хууль эрх зүйн баримт бичгүүд:

- Боловсролын хууль, 1991 он;

- Боловсролын тухай хууль, 1995 он;

- Боловсролын тухай хуулийн шинэчилсэн найруулга, 2002 он;

- Бага, дунд боловсролын тухай, 2002 онд тус тус батлагджээ.

Боловсролын тухай хууль бүтцийн хувьд боловсрол, сургалтын байгууллага болон боловсролын харилцаанд оролцогчдын эрх, үүргийг тодорхойлсон шинжтэй. Боловсролын тухай хуулийн шинэчилсэн найруулга 2002 онд батлагдсанаас хойш нийт 20 удаа нэмэлт өөрчлөлт оржээ (2012-2016 онд жил бүр тодорхой хэмжээнд өөрчлөлт орсон), 2016 онд 4 удаа, Боловсролын тухай хуулинд нийт 20 удаа нэмэлт, өөрчлөлт оруулсан нь 87,5 \% хувь буюу 48 зүйлийн 42 нь өөрчлөгдсөн гэсэн үг.

Төрийн албан ёсны хэл, монгол хэл, бичиг үсгээ эзэмших, хэрэглэх, хамгаалах, хөгжүүлэхтэй холбогдсон харилцааг зохицуулах зорилготой «Төрийн албан ёсны хэлний тухай» хуулийг 2003 онд анх удаа батлан хэрэгжүүлж улмаар уг хуулиа нэмэн өөрчилж «Монгол хэлний тухай хууль»-ийг 2015 онд батлан мөрдөж байна.

Энэхүү хууль батлагдсанаар их, дээд сургуульд элсэгчдээс авах элсэлтийн ерөнхий шалгалт болон төрийн албанд анх орох иргэнээс авах монгол хэлний шалгалт авах, монгол хэл бичгээ хэрэглэхийг Монгол улсын нутаг дэвсгэрт хуульчилж өгсөн онцлогтой. 


\section{Монголоведение • Mongolian Studies • 2020 ๑ T. 12 • № 4}

\section{Дүгнэлт}

1. Бидний гурван насны ангиллаар хийсэн судалгаагаар кирилл бичгийн чадвар 59,33 \%-тай байгаа нь цаашид илүү өргөн судалгааг хийж бодлого боловсруулах хэрэгтэйг харулж байна.

2. Бичиг үсгийн чадварыг дээшлүүлэхэд жил бүр олон нийтээс «Эх хэлний талаарх» судалгаа авч, шийдвэрлэдэг Япон улсын туршилгаас суралцах.

3. Монгол хүний бичиг үсгийн чадварт боловсрол, мэргэжил төдийлөн нөлөөлөхгүй, харин тухайн насны ангилал чухал нөлөөтэй нь судалгаанаас харагдаж байна. Ахмад насныханы гаргаж буй зөв бичгийн дүрмийн алдаа нь «Журамласан толь»-д туссаныг мэдэхгүйгээс болсон нь түгээмэл байна.

4. Эрхзүйн орчны хувьд бодлогын баримт бичиг, хууль цөөнгүй батлагдсан боловч тэдгээр нь тогтвортой хэрэгжиж чадахгүй байгаа тул дагаж мөрдөхөд бэрхшээлтэй байдаг нь боловсролын чанар стандартад сөргөөр нөлөөлж, сургалтын чанар, суралцагсдын чадварт нөлөөлж буй нь 30-аaс доош насныхны бичиг үсгийн чадварын түвшингөөс харагдаж байна.

5. Монгол хэлний чадвараа сайн дураар сорих бүх нийтийн «цээж бичиг»-ийн аяныг жил бүр «Эх хэлний өдөр»-өөр зохион байгуулж хэвшүүлэх.

\section{Литература}

Бондалетов 1987 - Бондалетов В. Д. Социальная лингвистика. М.: Просвещение, $1987.156 \mathrm{c}$.

Гэрэлмаa 2012 - Гэрэлмаа Г. Хэрэглээний хэл шинжлэл. Улаанбаатар: Сансудай, 2012. $167 \mathrm{x}$.

Хэлний бодлогыг оновчтой болгох асуудал 2007 - Хэлний бодлогыг оновчтой болгох асуудал. Монгол улсын ШУА-ийн нийгмийн шинжлэх ухааны салбарын Бага чуулган // Ажлын хэсгийн илтгэл, дүгнэлт, социологийн судалгаа. Улаанбаатар, 2007. $41 \mathrm{x}$.

Чулуунбаатар 2002 - Чулуунбаатар Л. Нүүдэлчин монголчуудын бичиг үсгийн соёл. Улаанбаатар: МУИС-ийн Хэвлэх үйлдвэр, 2002. 251 х.

Шагдарсүрэн 2001 - Шагдарсүрэн Ц. Монголчуудын бичиг үсгийн товчоон. Улаанбаатар: «Урлах эрдэм» хэвлэлийн газар, 2001. 300 х.

Ширнэн 2006 - Ширнэн Б. Үсэг бичгийн талаархи бодлого. Улаанбаатар: Тоонотпринт, 2006. $200 \mathrm{x}$.

\section{References}

Bondaletov V. D. Social Linguistics. Moscow: Prosveshchenie, 1987. 156 p. (In Russ.)

Chuluunbaatar L. Mongolian Nomads: The Culture of Written Literacy. Ulaanbaatar: National University of Mongolia, 2002. 251 p. (In Mong.)

Gerelmaa G. Applied Linguistics. Ulaanbaatar: Sansuday, 2012. 167 p. (In Mong.)

Optimizing Language Policies. Social Science Conference Proceedings (Summarizing Report, Conclusions, Social Survey). Ulaanbaatar: Mongolian Academy of Sciences, 2007. 41 p. (In Mong.)

Shagdarsüren Ts. Literacy Bureau of Mongolia. Ulaanbaatar: Urlakh Erdem, 2001. 300 p. (In Mong.)

Shirnen B. The Policy of Literacy. Ulaanbaatar: Toonotprint, 2006. 200 p. (In Mong.) 